\title{
Grammatical Error Analysis of English Abstracts Translation in Jurnal Ilmiah Ekonomi Islam (JIEI) Journal
}

\author{
Tira Nur Fitria ${ }^{1}$ \\ ${ }^{1}$ Institut Teknologi Bisnis AAS Indonesia, Sukoharjo, Indonesia
}

\begin{tabular}{|c|c|}
\hline Article History & Abstract \\
\hline $\begin{array}{r}\text { Submitted date: } \\
\text { 2021-07-30 } \\
\text { Accepted date: } \\
\text { 2021-09-27 } \\
\text { Published date: } \\
2021-11-17 \\
\end{array}$ & $\begin{array}{l}\text { Scientific writing like abstract demands perfect grammar writing in academic language. } \\
\text { A common error usually is the use of an automated translator such as Google Translate } \\
\text { to translate abstracts from Indonesian to English. The translation produced needs to be } \\
\text { polished again to avoid mistakes in the grammar itself. The objective of this research is } \\
\text { to find the types of grammatical errors in English abstracts published in Jurnal Ilmiah }\end{array}$ \\
\hline $\begin{array}{l}\text { Keywords: } \\
\text { error analysis; } \\
\text { grammatical error; } \\
\text { grammar; abstract; article; } \\
\text { journal }\end{array}$ & $\begin{array}{l}\text { descriptive qualitative one. The result of the study shows that three types of } \\
\text { grammatical errors found in English abstracts in the JIEI journal are misinformation, } \\
\text { omission, and addition. In misinformation error, there are } 98 \text { data or } 44.5 \% \text {. In } \\
\text { omission error, there are } 69 \text { data or } 31.36 \% \text {. In addition to error, there are } 53 \text { data or } \\
24.09 \% \text {. In misinformation, several errors were found in the use of part of speech such } \\
\text { as article/determiner, the preposition, verb (subject-verb agreement), noun (singular- } \\
\text { plural), and pronoun. In omission, several errors were found in the omission of part of } \\
\text { speech such as article 'a, an, the', preposition 'on' and 'to'. In addition, several errors } \\
\text { were found in the addition part of speech such as article/determiner 'a, an, the", } \\
\text { preposition "of, to, in, on, at". Preposition sometimes is not used with certain verbs and } \\
\text { expressions. The most dominant type of grammatical error is misinformation. There is } \\
\text { the misuse of grammar forms into other grammatical forms in the use of part of speech } \\
\text { such as determiner/article, preposition, verb, noun, and pronoun. }\end{array}$ \\
\hline
\end{tabular}

\section{Kata Kunci:}

analisis kesalahan; kesalahan tata bahasa; tata bahasa; abstrak; artikel; jurnal

\begin{abstract}
Abstrak
Analisis Kesalahan Tata Bahasa dalam Terjemahan Abstrak Bahasa Inggris pada Jurnal Ilmiah Ekonomi Islam (JIEI)

Karya tulis ilmiah seperti abstrak menuntut tata bahasa yang sempurna dalam bahasa akademik. Kesalahan umum biasanya adalah penggunaan penerjemah otomatis seperti Google Translate untuk menerjemahkan abstrak dari bahasa Indonesia ke bahasa Inggris. Terjemahan yang dihasilkan perlu dipoles lagi untuk menghindari kesalahan tata bahasa itu sendiri. Tujuan dari penelitian ini adalah untuk menemukan jenis kesalahan tata bahasa dalam abstrak bahasa Inggris yang diterbitkan dalam jurnal Jurnal Ilmiah Ekonomi Islam (JIEI) tahun 2020 dalam bahasa Inggris dan bahasa Indonesia. Penelitian ini bersifat deskriptif kualitatif. Hasil penelitian menunjukkan bahwa tiga jenis kesalahan tata bahasa yang ditemukan dalam abstrak bahasa Inggris di jurnal JIEI adalah misinformation, omission, dan addition. Pada misinformation error terdapat 98 data atau 44,5\%. Pada omission error terdapat 69 data atau 31,36\%. Selain itu error sebanyak 53 data atau 24,09\%. Dalam misinformasi, ditemukan beberapa kesalahan dalam penggunaan part of speech seperti kata sandang, preposisi/kata depan, kata kerja (subject-verb agreement), kata benda (tunggaljamak), dan kata ganti. Pada penghilangan, ditemukan beberapa kesalahan dalam
\end{abstract}

Corresponding author:

${ }^{1}$ tiranurfitria@gmail.com 
penghilangan part of speech seperti article 'a, an, the', preposition 'on' dan 'to'. Selain itu, ditemukan beberapa kesalahan dalam penambahan part of speech seperti kata sandang $a$, an, the, preposisi of, to, in, on, at. Preposisi terkadang tidak digunakan dengan kata kerja dan ekspresi tertentu. Jenis kesalahan tata bahasa yang paling dominan adalah kesalahan misinformasi. Terdapat penyalahgunaan bentuk gramatika ke dalam bentuk gramatikal lain dalam penggunaan kelas kata seperti kata benda/artikel, kata depan, kata kerja, kata benda, dan kata ganti.

\section{Introduction}

An abstract is one of the parts of scientific writing such as in a journal (Fitria, 2018b). Brookshire \& Brundage (2015, p. 113) state that most scholarly journals print an abstract at the beginning of each article. For any published text, a scientific paper usually allows English abstract to be written (Fitria, 2020a). In general, an abstract is simple writing that is not too long. A quick, concise, and easily understood restatement of it is an important part of compiling a scientific paper. An abstract is a brief digest of the contents of scientific papers, such as theses, dissertations, or research reports/journals. Abstract is one of the things that stands out in a scientific paper which is usually placed in the first part of a paper.

Writing abstracts in scientific English is not easy to do for those who have or who do not have adequate knowledge of English. Their lack of understanding may be caused by linguistic and nonlinguistic aspects that are needed to express thoughts or ideas. In terms of language, they must pay attention to the aspects of good and correct writing so that the ideas contained in a paragraph can be understood properly, including content, organization of ideas, use of language, vocabulary, and use of punctuation. The actualization of this understanding will be related to writing containing words and sentences that are well structured because it fulfills the elements of cohesion and coherence as a good paragraph. This means that they use lexical strings that relate to the content of the text and blend into the context of the text. Thus, they will make it easier for readers to understand their ideas because of the harmonization of linguistic elements in their writing as a medium for sharing knowledge and knowledge with others.

Along with times, scientific research abstracts have been made in two languages, namely Indonesian and English (Fitria, 2020a). Writing abstracts in English is a response to advances in science and technology where scientific works are published via the internet so that these scientific works can be accessed globally. Therefore, translating abstracts from Indonesian into English is very crucial. Abstract in the English version must be written following the rules of good and correct English writing, in this case, it must be written with the appropriate type of sentence and appropriate tenses. Because an abstract is one of the main components of scientific writing in a formal language, grammar is an important factor that should not be ignored in abstract writing.

The term 'grammar' can be used to refer to the system itself (Young, 2013, p. 12). When we talk of 'the grammar of English', it means the rules which constitute the language. Grammar is a collection of rules that describe how to properly organize words and groupings of words to create sentences in a language (Cowan, 2008, p. 3). He adds that "English grammar consists of all the rules that govern the formation of English sentences. Grammar itself is not very important in spoken language as long as the information conveyed can be received completely and the interlocutor can understand its meaning.

Scientific writing demands perfect grammar writing like academic language in general. A common error is to use an automated translator such as Google Translate to translate abstracts from Indonesian to English. The translation produced by the engine is still "raw" and needs to be polished again to avoid mistakes in the ignition of meaning or grammar itself. Even though it seems more expensive, entrusting abstract translation to professional translators is a wise choice. Besides, to ensure that the translation results are more guaranteed, the researcher does not need to be bothered with repeated revisions just because the writing of the abstract is not appropriate. Related to the error, 
the researcher here analyzes these errors by using 'error analysis'. James (2013, p. 1) states that the technique of identifying the occurrences, type, cause, and consequences of poor language usage is known as error analysis. Barry et al. (2010, p. 13) define error analysis as a particularly effective method of providing feedback.

There are several previous studies about 'grammar error'. This research wants to look for similarities and differences. The first research was written by Hidayati (2016). The results show that the grammatical errors contained in the abstract were in the form of omission, addition, misformation, and misordering. This is due to several factors, namely carelessness, first language interference, and translation. The most dominant error in this study is in the misformation category (19 errors) while the least error occurs in the misordering category (1 error). The second research was written by Qamariah et al. (2020). The results show that there were 11 categories of types of grammatical error; error in the use of the verb, tense, singular/plural noun, adjectives, preposition, to be, articles, modal/auxiliary, noun, objective pronoun, and phrasal verb with a total of 48 grammatical errors produced by students in their writing sheet. The third research was written by Bahar (2017). The data analysis results indicate that there are several types of grammatical errors that students create in writing proposals, especially in the agreement on subject-verb, number agreement, relation, word order, omitted subject, and omitted verb. Digit agreement is the most common grammatical mistake that learners produce in writing proposals. The fourth research was written by Tohkhwan (2019). The results of the study indicate that syntactic and lexical grammar are the most frequent grammatical errors made by IBF participants. Syntactically, IBF participants normally fail to add preposition, auxiliary, place the incorrect auxiliary, and omit apostrophes. The fifth research was written by Kurniasih (2017). The study outcome reveals that grammatical error types that produce omission error, inclusion error, misinformation, misordering. It can be inferred that the translation output by Google Translate from Indonesian to English is not reliable since it is translated word by word. Therefore, a rule in English and neglected the context is not appropriate. Accordingly, the translation must be edited. The sixth research, written by Uktolseja (2020), draws the hypothesis that there are many grammatical errors in songs such as conditional statement, subject-verb agreement, pronoun, negator, and auxiliary verbs.

Related to the previous studies above, similarities and differences appear with this research. The first research analyzes the error in the abstract of the students' thesis, the second research analyzes the error in the abstract of student's essay, the third research analyzes the error in the abstract of the students' proposal, the fourth research analyzes the error in WhatsApp group, the fifth research analyzes the error in abstract in Google Translate, and the sixth research analyzes the error in song lyrics, while this research analyzes the error in English abstracts' articles in the journal (Schmid, 2012, p. 63). The impression that an expression or even a whole text is 'abstract' can arise from various sources such as in article journals.

Hailman \& Strier (2006, p. 70) state that because many journals offer free electronic access to publish abstracts but not full articles, an abstract is the most essential section of the report for a simple reason: more people will read it than the entire document. In this paper, the researcher is interested in analyzing the error especially in the grammatical aspect of abstracts of English articles which have been published in a journal. Therefore, the purpose of this research is to find the types of grammatical errors in English abstracts published in Jurnal Ilmiah Ekonomi Islam (JIEI) journal, especially in the 2020 edition. The official language of the manuscript to be published in the JIEI journal is English and Indonesian, but the abstracts are written in English.

\section{Research Method}

Descriptive qualitative research was used in this research. Qualitative research focuses on understanding and analyzing the natural setting, for example setting in everyday life of a phenomenon from a subject or object (Neergaard \& Ulhøi, 2007, p. 383). Kumar (2010) states that "...qualitative, it is designed either to gain in-depth knowledge or information about a situation...". This research 
attempts to describe and interpret phenomena that happened during the study. This study seeks to describe and interpret what happened and reveal the meaning.

Documentation is used for collecting data in this research. Document as the 'umbrella' terms refers to a wide range for collecting data, for example, written proof, digital, visual, physical material relevant to the study (Merriam, 2009, p. 139). In this research, the example of a document used is an article that is published in Jurnal Ilmiah Ekonomi Islam (JIEI). The official language of the manuscript to be published in the JIEI journal is English and Indonesian. However, in this research, the research only analyzes English abstracts published in JIEI especially in the 2020 edition. The steps for analyzing data in this research are collecting several English abstracts published in the journal JIEI, identifying errors, classifying errors into the types of grammatical errors, displaying the result of analysis into a table by using the percentage of each error and concluding the data descriptively.

\section{Findings and Discussion}

\subsection{Findings}

The purpose of this study is to determine the types of grammatical errors discovered in the JIEI Journal and the most common types of grammatical errors found in the JIEI Journal. These grammatical errors in the JIEI journal here consist of several types of errors such as misinformation, omission, and addition. The examples are as follows:

\section{Misinformation}

The misinformation errors found were as follows:

\section{a. Article/determiner}

Example of misinformation in article/determiner:

(1) ... and from the calculation of the combination of strategies. It is also obtained if the highest value acquisition is in the combination of strategies so with a acquisition value of 4.59 (JIEI Vol.06, No. 01, 2020)

The example above shows that the article 'a' may be incorrect. The article should agree with the beginning vowel sound of the following word 'acquisition'. The correct article is 'an'. The article 'an' is used on words whose first syllable is a vowel. So, using the article 'an' in pronouncing the first syllable sounds vocal and focus on pronunciation, not spelling.

\section{b. Preposition}

Some examples of misinformation in a preposition are:

(1) Because it is supported and encouraged from the company and within the family. In terms of service quality,... (JIEI Vol.06, No. 02, 2020)

(2) This study aims to analyze the existence of micro waqf banks and their implications for public welfare in an Islamic perspective (JIEI Vol.06, No. 02, 2020)

(3) It indicates that in business activity, hadis of Prophet Muhammad SAW put more emphasis in importance of process of business ethics (JIEI Vol.06, No. 02, 2020)

(4) this research is to describe respondent characteristics and to analyze factors that affecting people's perception on cash waqf (JIEI Vol.06, No. 02, 2020)

(5) The result shows people's perception on cash waqf is significantly influenced by internal factor... (JIEI Vol.06, No. 02, 2020)

(6) Furthermore, foreign debt in the long term hurt economic growth, but for the short term, it could bring the positive one (JIEI Vol.06, No. 03, 2020)

(7) This study aims to determine the effect of poverty, unemployment, economic growth, and government spending on the Human Development Index (HDI) in Indonesia in 2014-2018 in an Islamic perspective (JIEI Vol.06, No. 02, 2020) 
(8) This study aims to analyze the existence of micro waqf banks and their implications for public welfare in an Islamic perspective (JIEI Vol.06, No. 03, 2020)

The example above shows that the prepositions used may be incorrect in those sentences. In the $1^{\text {st }}$ abstract, the preposition 'from' which is followed by the verb 'encouraged' as V3 is incorrect in the sentence. The correct preposition is 'by'. When we want to say who or what did an action in the passive voice, we use the preposition 'by'. The preposition 'by' is used to denote the person doing something in the passive voice. In the $2^{\text {nd }}$ and $7^{\text {th }}$ abstract, the preposition 'in' is incorrect in the sentence. The correct preposition is 'from'. In the $3^{\text {rd }}$ abstract, the preposition 'in' is incorrect in the sentence. The correct preposition is 'on'. In the $4^{\text {th }}$ and $5^{\text {th }}$ abstract, the preposition 'on' is incorrect in the sentence. The correct preposition is 'of'. In the $6^{\text {th }}$ abstract, the preposition 'for' is incorrect in the sentence. The correct preposition is 'in'.

\section{c. Verb}

Some examples of misinformation in a verb, for example:

(1) Research variable used promotion cost and training cost which were allocated by Islamic Rural Bank... (JIEI Vol.06, No. 01, 2020)

(2) The survey conducted on Muslim students of Universitas Pendidikan Indonesia which distributed online (JIEI Vol.06, No. 01, 2020)

(3) Qualitative descriptive research method using Ethnographic Content Analysis (ECA) technique from annual reports with purposive sampling technique are BNI Syariah, Bank Syariah Mandiri and BRI Syariah (JIEI Vol.06, No. 01, 2020)

(4) One of the problems that is very important to be considered by a country or region is infrastructure problems that will have an impact on the sustainability of the region's economic development (JIEI Vol.06, No. 02, 2020)

(5) Stock price are independent variable and dividend per share, earning per share, and return on equity as a dependent variable (JIEI Vol.06, No. 03, 2020)

The examples above show that the verbs used may be incorrect in those sentences. In the $1^{\text {st }}$ example, the plural verb 'were' does not appear to agree with the singular subject 'training cost'. It should be changed into the correct verb form for subject-verb agreement. In the $2^{\text {nd }}$ example, there is a missing verb in 'conducted' and 'distributed'. 'To be' should be added to form a passive voice. The correct verb is 'is' or 'was' then followed by 'conducted' and 'distributed' as verb 3 . In the $3^{\text {rd }}$ example, the verb 'are' does not seem to agree with the subject 'qualitative descriptive research method' in a singular subject form. It should be changed into the singular verb 'is'. In the $4^{\text {th }}$ example, the singular verb 'is' does not appear to agree with the plural subject of the problems. It should be changed 'are'. In the $5^{\text {th }}$ example, the plural verb 'are' does not seem to agree with the subject. Consider changing the verb form. It should be changed into 'is'.

(6) Meanwhile, the shock of FDR, ROA, Leverage, and Size bank have significant effect on S-Score (JIEI Vol.06, No. 01, 2020)

(7) This study show that dividend per share, earning per share, and return on equity (JIEI Vol.06, No. 03, 2020)

(8) This study uses SmartPLS assistance program version 2.0 as a test of the hypothesis that exist in this study (JIEI Vol.06, No. 03, 2020)

The examples above show that the verbs used may be incorrect in those sentences. In the $6^{\text {th }}$ example, the verb 'have' does not seem to agree with the subject. It should be changed into 'has'. In the $7^{\text {th }}$ example, the verb 'show' does not seem to agree with the subject. Consider changing the verb form. It should be changed into 'shows'. In the $8^{\text {th }}$ example, the plural verb 'exist' does not appear to agree with the singular subject of 'hypothesis'. It should be changed into 'exists'. 


\section{d. Noun}

Some examples of misinformation in a noun are:

(1) To see how consumption behavior in the perspective Islamic economics, the author wants to analyze rationally (JIEI Vol.06, No. 01, 2020)

(2) Sampling is used by using a system random sampling, the technique is a sampling technique where all individuals in the population (JIEI Vol.06, No. 02, 2020)

The $1^{\text {st }}$ example above shows that the word 'consumption' does not seem to fit this context. It should be changed into 'consumer'. While the $2^{\text {nd }}$ example above shows that the word 'system' does not seem to fit this context. It should be changed with a different one into 'systematic'.

(3) Brand equity is one of the most critical issue of marketing. It has four indicator such as brand awareness, brand loyalty, brand associations and perceived value which affect purchase intention (JIEI Vol.06, No. 01, 2020)

(4) The research data is collected by distributing questionnaires to 100 respondent (JIEI Vol.06, No. 03, 2020)

The $3^{\text {rd }}$ and $4^{\text {th }}$ examples above show that the singular countable noun 'issue' and 'respondent' follow the quantifier 'one', which requires a plural noun. It should use a plural noun or a different quantifier. The correct word is 'issues' and 'respondents'. The singular noun 'indicator' follows a number other than one. The noun should be changed into the plural form. The correct word is 'indicators' so it agrees in number with other words in the phrase.

\section{e. Pronoun}

Some examples of misinformation in a pronoun are:

(1) Entrepreneurs should keep the orientation of this blessing to be the vision of it business,... (JIEI Vol.06, No. 02, 2020)

(2) As a country, Indonesia is inseparable from import activities to meet their own needs (JIEI Vol.06, No. 02, 2020)

The $1^{\text {st }}$ example above shows that there is a pronoun problem 'it' in the sentence. The correct pronoun is 'its' because refers to the subject 'entrepreneurs' as a plural noun. The $2^{\text {nd }}$ example above shows that there is a pronoun problem 'their' in the sentence. The correct pronoun is 'its' because it refers to the subject 'Indonesia' as a singular pronoun.

\section{Omission}

Omission errors were found as follows:

(1) The role of State Sukuk has a very positive impact, such as financing project development, encouraging development of the Islamic financial market,... (JIEI Vol.06, No. 01, 2020)

(2) Meanwhile, halal label has negative significant effect to purchase intention of Muslim student Universitas Pendidikan Indonesia (JIEI Vol.06, No. 01, 2020)

(3) Meanwhile, investors in the capital market are still low when compared the total population of Indonesia, ... (JIEI Vol.06, No. 02, 2020)

(4) The results of this study are that the board of commissioners and internal control can reduce fraud,... (JIEI Vol.06, No. 02, 2020)

The example in the $1^{\text {st }}$ example above shows that the noun phrase 'development' seems to be missing a determiner before it. Therefore, the article 'the' should be added into 'the development". In the $2^{\text {nd }}$ example, it seems that the preposition 'to' may be incorrect in the sentence. The correct preposition is 'on to' because the verb 'effect' must be followed by the preposition 'on'. In the $3^{\text {rd }}$ example, it seems that article 'the' may be incorrect in the sentence. The correct preposition is 'to' 
because the verb 'compared' must be followed by the preposition 'to'. In the $4^{\text {th }}$ example, the noun phrase 'internal control' seems to be missing a determiner before it. So that, it should be added by the article 'an' into 'an internal control'.

\section{Addition}

Addition errors were found as follows:

(1) However, Indonesia must face various challenges such as the low halal awareness, low local product competitiveness, and problems in implementing the Halal Product Guarantee Regulation (JIEI Vol.06, No. 01, 2020)

(2) Therefore, the purpose of this paper is to determine of how brand equity and halal label affect purchase intention of Lifebuoy products (JIEI Vol.06, No. 01, 2020)

(3) This research is a field research with a quantitative description (JIEI Vol.06, No. 01, 2020)

(4) Nowadays, millennials have become the market targetting of the banking sector, especially for using digital banking, since they prefer to something modern and instant (JIEI Vol.06, No. 01, 2020)

(5) The implementation of the model of technology acceptance (TAM) which includes two predictors including the perceived ease of use and perceived of usefulness (JIEI Vol.06, No. 01, 2020)

(6) In this study found several steps in the reconstruction of banking learning (JIEI Vol.06, No. 01, 2020)

(7) The results and findings of the study are the growth of zakat from each year, either from the growth of zakat in the online zakat system or in the overall zakat income (JIEI Vol.06, No. 01, 2020)

(8) Business ethics are gathered from guideline from the Prophet Muhammad SAW emphasized on two important things...(JIEI Vol.06, No. 02, 2020)

(9) The authors analyze and understand the factors in influencing the acceptance of a use through technology (JIEI Vol.06, No. 02, 2020)

(10) But the realization of cash waqf collection is still far from of the existing potential...((JIEI Vol.06, No. 02, 2020)

(11) This study explains about compensation and its effect on employee performance, where the spirit of work is used as a mediation variable (JIEI Vol.06, No. 02, 2020)

The $1^{\text {st }}$ example above shows that in the phrase 'the low halal awareness', the use of the article may be incorrect so that the article 'the' must be removed. The $2^{\text {nd }}$ example above shows that the clause 'how brand equity' may use the incorrect article 'the' so it must be removed. In the $3^{\text {rd }}$ example above, the indefinite article 'a' may be redundant when used with the uncountable noun 'research' in the sentence, so that the article ' $a$ ' must be removed. The $4^{\text {th }}$ example above shows that the preposition 'to' is incorrectly followed by the verb 'prefer'. So, the preposition 'to' must be removed. The $5^{\text {th }}$ example shows that the preposition 'of' is incorrectly followed by the verb 'perceived'. So, the preposition 'of' must be removed. In the $6^{\text {th }}$ and $7^{\text {th }}$ examples, the preposition 'in' in 'in this study' and 'in the overall' is not needed. So that, the preposition 'in' must be removed. In the $8^{\text {th }}$ example, the preposition 'on' is not needed in the sentence. So, the preposition 'on' must be removed. In the $9^{\text {th }}$ example above, the indefinite article ' $a$ ' may be redundant when used with the uncountable noun 'use' in the sentence. So, the article 'a' must be removed. In the $10^{\text {th }}$ example, the preposition 'of' is not needed, so it must be removed. Then, in the last example, the preposition 'about' also is not needed in the context, so it must be removed.

\subsection{Discussion}

Making an error in grammar is quite common. When writing English, sometimes the grammar still uses Indonesian grammar. Finally, the use of sentences in English becomes inappropriate (Fitria, 2018a, 2019a, 2019b, 2020b, 2020c). Based on the performance strategy, grammar errors can be divided into 1) omission, it occurs when a phrase or sentence loses one or more elements of language); 2) addition, this happens when a phrase or sentence contains one or more unnecessary additional language elements; 3) misformation, this occurs when the form of a phrase or sentence does not conform to the rules of the language; 4) misordering, this arrangement or sequence of language 
Fitria, T.N., (2021). Grammatical Error Analysis of English Abstracts Translation in Jurnal Ilmiah Ekonomi Islam (JIEI) Journal. LITE: Jurnal Bahasa, Sastra, dan Budaya 17 (2), 117-126. https://doi.org/10.33633/lite.v17i2.5050

elements in a phrase or sentence construction is outside or deviates from the rules of the language. In the JIEI journal, some types of grammatical errors were found, as stated in the table below:

Table 1. Grammatical Error of English Abstracts in JIEI Journal

\begin{tabular}{cccc}
\hline \multirow{2}{*}{ Aspect } & \multicolumn{3}{c}{ Type of Grammatical Error } \\
\cline { 2 - 4 } & Misinformation & Omission & Addition \\
\hline Data & 98 data & 69 data & 53 data \\
\hline Percentage & $44.55 \%$ & $31.36 \%$ & $24.09 \%$ \\
\hline
\end{tabular}

The table above shows that there are three types of grammatical errors found in English abstracts in the JIEI journal, they are misinformation, omission, and addition. In misinformation error, there are 98 data or $44.5 \%$. In omission error, there are 69 data or $31.36 \%$. In addition to errors, there are 53 data or $24.09 \%$. Based on the data obtained, it was found that the writers' English language errors that mostly appeared in the English abstract of JIEI are in misformation.

The first type of grammatical error is misinformation. It is the misuse of grammar forms into other grammatical forms (Ellis et al., 1994). There are several errors of misinformation in the use of part of speech. First, in the article/determiner. The article 'an' is used on words whose first syllable pronounces is vowels. So, using the article 'an' can be pronounced by the first syllable sounds vocal and focus on pronunciation, not spelling. Second, in the preposition, such as the use of the preposition 'in, on' of, from, by' etc. The other errors also happened in verb + preposition. For example, 'encouraged + by' refers to the passive voice. Third, in Verb. Both singular and plural subjects must follow the rule of subject-verb agreement. Subject-Verb Agreement is an adjustment between the verb (verb) and the subject of a sentence in terms of number, namely: singular (singular) or plural (plural). Subjects can be nouns (nouns), pronouns (pronouns), or other constructs that act as nouns, such as gerunds and infinitives. The singular subject uses the singular verb, while the plural subject uses the plural verb. Fourth, in a noun. Several nouns also do not seem with the context or sentence, so that the noun must be correct based on the sentence. The other noun error is the use of singular and plural nouns. Both the singular and plural countable nouns also must follow the subject agreement. Fifth, in pronoun. The pronoun must follow the verb which shows the singular or plural. Misinformation error is the most dominant error in this research. It is in line with the research from Hidayati (2016) that states the grammatical errors contained in the abstract were in the form of omission, addition, misformation, and misordering. This is due to several factors, namely carelessness, first language interference, and translation. The most dominant error in this study is in the misformation category.

The second error is omission. Omission error is removing a word or grammatical element needed in an expression related to grammar (Ellis et al., 1994). This happens where removing an element of a sentence that should exist to make the sentence grammatically correct. Several forms of omission errors were found, in part of speech such as article/determiner 'a, an, the', preposition 'on' and 'to'.

The third error is addition. An addition error is adding a word or grammatical element in an expression related to grammar (Ellis et al., 1994). The addition of elements in the sentence makes the sentence grammatically wrong. Several forms of addition errors were found, in part of speech such as article/determiner 'a, an, the", preposition "of, to, in, on, at". Prepositions sometimes are not used with certain verbs and expressions.

\section{Conclusion and Suggestion}

\subsection{Conclusion}

Abstract writing is indeed a difficult challenge, especially if it has to be translated into English. Making errors especially in grammar is quite common. Abstracts in the English version must be 
written by using good English writing rules for abstracts in scientific writings. Sentences in the abstract must be written with appropriate grammar. An abstract is one of the main components of scientific writing in a formal language, so grammar is an important factor that should not be ignored in abstract writing. In JIEI Journal, there are several types of grammatical errors found, such as misinformation, omission, and addition.

\subsection{Suggestions}

After knowing and discussing the result of this research, the researcher would like to conclude that many authors still make grammatical errors in writing English abstracts that are published in the journal. It means that the authors and the journal management should have paid more attention to revising and editing the articles especially English abstracts before publishing the articles.

\section{References}

Bahar, P. (2017). An Analysis of Grammatical Errors in Students' Proposals. Indonesian EFL Journal: Journal of ELT, Linguistics, and Literature, 3(2), 64-81. http://ejournal.kopertais4.or.id/mataraman/index.php/efi/article/view/3410

Barry, M., Campbell, B., \& Daish, S. (2010). Practice Tests for IGCSE English as a Second Language Reading and Writing Book 1. Cambridge University Press.

Brookshire, R. H., \& Brundage, S. B. (2015). Writing Scientific Research in Communication Sciences and Disorder. Plural Publishing.

Cowan, R. (2008). The Teacher's Grammar of English with Answers: A Course Book and Reference Guide. Cambridge University Press.

Ellis, R., Ellis, P. R., \& Ellis (taalkunde), R. R. (1994). The Study of Second Language Acquisition. Oxford University Press.

Fitria, T. N. (2018a). Error Analysis Found in Students' Writing Composition of Simple Future Tense. ELS Journal on Interdisciplinary Studies in Humanities, 1(3), 240-251. https://doi.org/10.34050/els-jish.v1i3.5028

Fitria, T. N. (2018b). Translation Technique of English Abstract Translation in Journal Edunomika in 2018. English and Literature Journal, 5(2), 145-160. https://doi.org/10.24252/elite.v5i2a4

Fitria, T. N. (2019a). Errors in Students' Writing Composition in Simple Present Tense "MY DAILY ACTIVITY." EDULANGUE, 2(1), 47-62. https://doi.org/10.20414/edulangue.v2i1.318

Fitria, T. N. (2019b). Students' Error Analysis In Writing English Composition Of "My Self Description. Proceeding SENDI_U, 453-460.

Fitria, T. N. (2020a). Error Analysis of English Abstract in International Journal of Economics, Business and Accounting Research (IJEBAR). Al-Lisan: Jurnal Bahasa (e-Journal), 5(2), 164-181. https://doi.org/10.30603/al.v6i2.1335

Fitria, T. N. (2020b). Error Analysis Found in Students' Writing Composition in Simple Past Tense of Recount Text. ENGLISH FRANCA: Academic Journal of English Language and Education, 4(2), 141-160. https://doi.org/10.29240/ef.v4i2.1154 
Fitria, T. N. (2020c). Error Analysis in Using Simple Past Tense Found in Students' Writing of Recount Text. ADJES (Ahmad Dahlan Journal of English Studies), 7(1), 39-54. https://doi.org/10.26555/adjes.v7i1.12238

Hailman, J. P., \& Strier, K. B. (2006). Planning, Proposing, and Presenting Science Effectively: A Guide for Graduate Students and Researchers in the Behavioral Sciences and Biology. Cambridge University Press.

Hidayati, W. (2016). English Grammatical Errors in Abstract Section of Civil Engineering Students' Thesis of Diponegoro University. LANTERN (Journal on English Language, Culture and Literature), 5(1), Article 1. https://ejournal3.undip.ac.id/index.php/engliterature/article/ view/11408

James, C. (2013). Errors in Language Learning and Use: Exploring Error Analysis. Routledge.

Kumar, R. (2010). Research Methodology: A Step-by-Step Guide for Beginners. SAGE.

Kurniasih, I. (2017). Grammatical Error Analysis of Using Google Translate From Indonesia To English In Writing Abstract of the Students' of IAIN Metro [Undergraduate, IAIN Metro]. https://repository.metrouniv.ac.id/id/eprint/2756/

Merriam, S. B. (2009). Qualitative Research: A Guide to Design and Implementation. John Wiley \& Sons.

Neergaard, H., \& Ulhøi, J. P. (2007). Handbook of Qualitative Research Methods in Entrepreneurship. Edward Elgar Publishing.

Qamariah, H., Wahyuni, S., \& Meliana. (2020). An Analysis of Students' Grammatical Errors in Writing English Text of the Students SMK-SMTI Banda Aceh. Getsempena English Education Journal, 7(1), 58-71. https://doi.org/10.46244/geej.v7i1.1041

Schmid, H.-J. (2012). English Abstract Nouns as Conceptual Shells: From Corpus to Cognition. Walter de Gruyter.

Tohkhwan, S. (2019). Grammatical Error Analysis on Whatsapp Conversation Made by Members of International Badminton Family [Undergraduate, Universitas Islam Negeri Maulana Malik Ibrahim]. https://doi.org/10/1/14320158.pdf

Uktolseja, L. J. (2020). An Analysis of Grammatical Errors in Song Lyrics. INTERACTION: Jurnal Pendidikan Bahasa, 7(1), 1-7. https://doi.org/10.36232/jurnalpendidikanbahasa.v7i1.443

Young, D. J. (2013). Introducing English Grammar. Routledge. 